\title{
Influence of foliar urea on the phenology, growth and yield of maize applied at various growth stages
}

\author{
Subhanullah*, Riaz Muhammad Khan and Hamid Ur Rahman
}

Cereal Crops Research Institute (CCRI), Pirsabak Nowshera, Khyber Pakhtunkhwa-Pakistan

*Corresponding author's email: $\underline{\text { subhan_agri@yahoo.com }}$

Citation

Subhanullah, Riaz Muhammad Khan and Hamid Ur Rahman. Influence of foliar urea on the phenology, growth and yield of maize applied at various growth stages. Pure and Applied Biology. Vol. 6, Issue 1, pp247-255.

http://dx.doi.org/10.19045/bspab.2017.60020

\begin{tabular}{llll}
\hline \hline Received: 11/12/2016 & Revised: 07/02/2017 & Accepted: 10/02/2017 & Online First: 14/02/2017 \\
\hline
\end{tabular}

\section{Abstract}

Field trials were carried out for three consecutive years to investigate the influence of foliar urea on maize (Zea mays L.) applied at different growth stages at the Cereal Crops Research Institute (CCRI), Pirsabak Nowshera, Khyber Pakhtunkhwa-Pakistan during 2014-16. The experiment was conducted in RCBD with split plot arrangement using four urea levels $(\mathrm{N} 1=0, \mathrm{~N} 2=3, \mathrm{~N} 3$ $=5$ and $\mathrm{N} 4=7 \%$ urea) assigned to main plots and six application timings $[\mathrm{AS} 1=\mathrm{V} 7$, AS2 $=\mathrm{V} 10, \mathrm{AS} 3=\mathrm{R} 1$ Silking, AS4 $=\mathrm{V} 7+\mathrm{V} 10$ (foliar urea applied at both stages), AS5 = V7+R1 and AS6 $=\mathrm{V} 10+\mathrm{R} 1]$ allotted to subplots. Phenological characteristics of maize (tasseling, silking, and maturity) were significantly delayed with foliar urea spray @ 7\% and when applied at both V7+V10 stages respectively. Earlier days to tasseling, silking, and maturity were recorded in foliar urea control plots and with foliar urea application when sprayed only at R1 stage. Leaf area, plant height, cob length, grains $\mathrm{cob}^{-1}, 1000$ grain weight, stover and grain yields were significantly improved with $7 \%$ urea application. Maize growth and yield were significantly enhanced when foliar urea was applied at both $\mathrm{V} 7+\mathrm{V} 10$ stages respectively. It is concluded that urea foliar feeding @7\% when applied at both V7+V10 stages enhanced and prolonged vegetative growth period of maize and resulted in increased grain yield and yield components of maize.

Keywords: Maize; Foliar urea; Application stage; Growth; Yield and yield components

\section{Introduction}

Foliar feeding, referring to the application of plant nutrients to the foliage of plants, has been documented as early as 1844 , when foliar iron sulfate spray was applied for the possible remedy of "chlorosis sickness". Foliar feeding has been broadly used and recognized as an important factor of crop production. Although soil fertilization is the most effective and economic way of supplementing the major plant nutrient requirements, foliar feeding has proven to be an excellent method of supplying plant nutrients during short or critical growth stages. The prime purpose of foliar feeding is to delay the natural senescence shortly after the reproductive growth stages [1]. Foliar feeding during crop period when rate of photosynthesis declines and nutrient absorption occur aids in the translocation of nutrients into seed, fruit, tuber or vegetative production. Secondly, foliar feeding 
effectively influences the vegetative growth periods by reducing the induced stress of adverse growing conditions and limited nutrient availability [1].

Post flowering $\mathrm{N}$ uptake and grain protein contents were improved with near flowering $\mathrm{N}$ application [2]. Foliar urea when sprayed at anthesis and during flowering had increased grain $\mathrm{N}$ content [3]. Maize grain yield was significantly improved with urea spray as a supplemental dose at the rate of 7 $\mathrm{kg} \mathrm{N} \mathrm{ha}^{-1}$ [4]. Significantly higher grains ear 1,1000 grain weight, grain and stover yield were recorded with $6 \% \mathrm{~N}$ [5]. Foliar N when applied during late season had a significant effect on total grain $\mathrm{N}$, grain yield, total straw $\mathrm{N}$ and straw yield [6]. Foliar N significantly increased plant height, while earlier days to tasseling and maturity were observed with the decreasing $\mathrm{N}$ levels, whereas significantly higher plant was produced with foliar $\mathrm{N}$ fertilization [7].

Foliar urea spray had no significant effects on grain and stover yield probably due to the poor utilization of urea $\mathrm{N}$ applied after anthesis to improve accumulation of dry matter [8]. Significantly higher plant height, cob length, grains $\mathrm{cob}^{-1}$ and grain weight were recorded with increasing $\mathrm{N}$ levels [9]. The chlorotic leaves of $\mathrm{N}$ deficient maize regained their normal chlorophyll content and stomatal function with foliar urea application [10].

The application of foliar urea at the rate of $6 \%$ delayed days to tasseling, silking and maturity and improved yield and yield components of maize [11]. Application of urea through foliar spray had increased grain protein content of barley more effectively than broadcast [12]. Significant effects of nitrogen management have been reported on the growth, phenology and grain yield of maize $[13,14]$.

Studies on the most effective levels of foliar urea and the critical growth stages of maize for foliar urea application in this agro- ecological zone of Khyber Pakhtunkhwa province of Pakistan have not been carried out. Therefore, this study was designed to investigate the comparatively more effective levels of foliar urea and their appropriate application stages for enhancing growth and yield of maize.

\section{Materials and methods}

Experimental trials were conducted at the Cereal Crops Research Institute (CCRI), Pirsabak Nowshera, Khyber PakhtunkhwaPakistan, during 2014-16. The climate of Nowshera is prevailed by hot relatively long summers and cold but short winters. The institute is situated on the left bank of river Kabul about $1600 \mathrm{~km}$ north of Indian Ocean at $34^{\circ} \mathrm{N}$ latitude, $72^{\circ} \mathrm{E}$ longitude and has an altitude of $288 \mathrm{~m}$ above sea level. The Soil was calcareous in nature, sandy loam, low in AB-DTPA extractable $\mathrm{P}\left(3.5 \mathrm{mg} \mathrm{kg}^{-1}\right)$, organic matter $(0.85 \%)$, alkaline in reaction ( $\mathrm{pH}$ 8.0) and moderate in AB-DTPA extractable K (90 mg kg-1). Nitrogen content of soil was also low and measured about $0.085 \%$ before the experiment. The mean annual rainfall varies from 450 to $750 \mathrm{~mm}$. Erratic rainfalls occurred mostly in spring in March and particularly in summer from June to August. Mean temperature of the crop growth season was $30.85 \pm 3^{\circ} \mathrm{C}$ during summer 2014-16, however the maximum mean temperature was $36.8 \pm 3^{\circ} \mathrm{C}$ and minimum was $24.6 \pm 3^{\circ} \mathrm{C}$, with a relative humidity $57.5 \%$.

The experiments were conducted for three consecutive years in randomized complete block design with split-plot arrangement using three replications. Four urea levels, N1 $=$ control, $\mathrm{N} 2=3 \%, \mathrm{~N} 3=5 \%$, and $\mathrm{N} 4=7 \%$, were assigned to main plots and six application stages, AS $1=\mathrm{V} 7$ (collar of $7^{\text {th }}$ leaf was visible), AS2 $=\mathrm{V} 10$ (collar of $10^{\text {th }}$ leaf was visible), AS3 = R1 (silks were visible), AS4 = V7+V10 (foliar urea was applied at both stages respectively), AS5 = $\mathrm{V} 7+\mathrm{R} 1$ and $\mathrm{AS} 6=\mathrm{V} 10+\mathrm{R} 1$, were allotted to 
subplots. Each subplot consisted of 6 rows, $5 \mathrm{~m}$ long with row to row distance of $75 \mathrm{~cm}$ and plant to plant distance of $20 \mathrm{~cm}$. Basal doze of N-P-K was applied at the rate of 60$90-60 \mathrm{~kg} \mathrm{ha}^{-1}$ at the time of sowing as urea $(46 \% \mathrm{~N})$, single super phosphate (18\% $\left.\mathrm{P}_{2} \mathrm{O}_{5}\right)$ and sulfate of potash $\left(50 \% \quad \mathrm{~K}_{2} \mathrm{O}\right)$ respectively. Maize variety Jalal-2003 was used as a test crop. All required cultural practices were uniformly applied to all experimental plots.

Urea solution for each treatment was prepared by dissolving the respective calculated amount of urea in six-liter water sufficient to fully wet one experimental unit when sprayed. Foliar urea sprays were applied at the specified growth stages during late evening and early morning hours when environmental conditions were warm, moist and calm which favor highest tissue permeability.

Days to tasseling and silking were counted from the date of emergence till 50\% tassels Grain Yield $\left(\mathrm{Kg} \mathrm{plot}^{-1}\right)=\left(\underline{100-\text { Moisture }(\%) \text { at harvest }) \times \text { Fresh ear weight } \text { plot }^{-1}(\mathrm{Kg}) \times \operatorname{Shelling}(\%)}\right.$ $(100$-Store grain moisture $(15 \%)) \times 100$

Grain Yield $\left(\mathrm{t} \mathrm{ha}^{-1}\right)=\underline{\left.\text { Grain yield }\left(\mathrm{Kg} \text { plot }^{-1}\right) \times 10000 \mathrm{~m}^{2} \times \text { ton }\right)}$

Plot size $\left(\mathrm{m}^{2}\right) \times 1$ ha $\times 1000 \mathrm{Kg}$

Analysis of variance procedure was followed for the statistical analysis of data based on randomized complete block design with split plot arrangement [16]. Means were compared using least significant difference (LSD) test at $\mathrm{P} \leq 0.05$ upon significant F-test.

\section{Results}

\section{Phenology and growth}

Phenology (days to tasseling, silking and maturity) and growth of maize (plant height and average leaf area) were significantly improved with foliar urea feeding at various growth stages (Table 1). Days to tasseling were delayed to 53 days with the application of foliar urea @ 7\%,followed by 51 days to tasseling when foliar urea was applied @ 5\%. Earlier days to tasseling (47) were recorded in control plots. Days to tasseling were prolonged to 53 days when foliar urea was applied at both V7+V10 stages and silks appeared in each treatment. Days to maturity were counted from sowing till the plants were fully matured. Plant height of ten randomly selected plants was measured from ground level to top in each subplot and then averaged. Average leaf area was determined by measuring the length and width of five middle leaves from ten randomly selected plants in each subplot using the formula: Average Leaf area $=$ Leaf L x Leaf W x 0.75 [14]. Cob length of ten randomly selected cobs was measured from each subplot and then averaged. From each treatment ten cobs were randomly selected and the number of grains $\operatorname{cob}^{-1}$ was counted and then averaged. Grain weight was determined by weighing 1000 grains randomly taken from the grain lot of each subplot. The stover of maize harvested from all six rows of each subplot was dried and weighed to estimate stover yield. Grain yield from each subplot was determined using the following formula [15].

respectively. Application of foliar urea at both $\mathrm{V} 7+\mathrm{R} 1$ stages resulted in 51 days to tasseling on a par with when foliar urea was sprayed only at the V7 stage. Earlier days to tasseling (47) were observed when urea was applied only at R1 stage.

Foliar urea levels and application stages had a significant effect on days to silking (Table 1). Days to silking were delayed to 55 days when foliar urea was applied @ 7\%, followed by 53 days to silking when sprayed @ 5\%. Earlier days to silking (49) were observed in control plots. Days to silking were advanced to 55 days when foliar urea was sprayed at both $\mathrm{V} 7+\mathrm{V} 10$ stages respectively, followed by foliar urea spray at both $\mathrm{V} 7+\mathrm{R} 1$ stages resulting in 53 days to silking. Earlier days to silking (49) were observed when urea was applied only at R1 stage. 
Days to maturity were significantly delayed with foliar urea application at various growth stages (Table 1). Days to maturity were delayed to 97 days when foliar urea was applied @ 7\%, followed by 95 days to maturity when sprayed @ 5\%. Earlier days to maturity (90) were observed in control plots. Foliar urea sprays delayed days to maturity (97) when applied at both V7+V10 stages respectively, followed by days to maturity (95) when sprayed at both $\mathrm{V} 7+\mathrm{R} 1$ stages. Earlier days to maturity (90) were observed when foliar urea was applied only at R1 stage.

Foliar urea levels and application stages produced a significant effect on plant height (Table 1). Plant height was $177 \mathrm{~cm}$ tall when foliar urea was applied @ 7\%. Foliar urea application@ @ 0 produced $169 \mathrm{~cm}$ tall plants on a par with $(165 \mathrm{~cm})$ when applied @ 3\%. Lowest plant height $158 \mathrm{~cm}$ was produced in control plots. Spray of foliar urea at both V7+V10 stages resulted in 176 $\mathrm{cm}$ tall plants on a par with foliar urea application at both V10+R1 stages with 172 $\mathrm{cm}$ plant height. Plant height was lowest 160 $\mathrm{cm}$ when foliar urea was sprayed only at R1 stage.

Average leaf area was significantly affected by foliar urea levels and application stages (Table 1). Average leaf area was $353 \mathrm{~cm}^{2}$ wider when applied with foliar urea @ 7\%. Foliar urea application@ @\% produced 341 $\mathrm{cm}^{2}$ broader average leaf area on a par with $\left(336 \mathrm{~cm}^{2}\right)$ when sprayed @ 3\%. Lowest average leaf area $318 \mathrm{~cm}^{2}$ was produced in control plots. Foliar urea when sprayed at both $\mathrm{V} 7+\mathrm{V} 10$ stages produced $356 \mathrm{~cm}^{2}$ wider average leaf area. Application of foliar urea spray at both $\mathrm{V} 10+\mathrm{R} 1$ stages resulted in $346 \mathrm{~cm}^{2}$ average leaf area as compared to the lowest $323 \mathrm{~cm}^{2}$ average leaf area produced when foliar urea was applied only at R1 stage.

Table 1. Tasseling (days), silking (days), maturity (days), plant height (cm), and avg. leaf area $\left(\mathrm{cm}^{2}\right)$ of maize as affected by foliar urea application at different growth stages

\begin{tabular}{|l|l|l|l|l|l|}
\hline Treatments & Tasseling & Silking & Maturity & Plant height & Leaf area \\
\hline Foliar Urea levels (N) & 47 & 49 & 90 & 158 & 318 \\
\hline N1=Control & 47 & 51 & 93 & 165 & 336 \\
\hline N2=3\% Urea & 50 & 53 & 95 & 169 & 341 \\
\hline N3=5\% Urea & 51 & 55 & 97 & 177 & 353 \\
\hline N4=7\% Urea & 53 & 0.51 & 0.52 & 3.44 & 7.48 \\
\hline LSD (0.05) & 0.76 & 52 & 94 & 163 & 326 \\
\hline Application stages (AS) & 51 & 51 & 93 & 164 & 336 \\
\hline AS1=V7 & 49 & 49 & 90 & 160 & 323 \\
\hline AS2=V10 & 47 & 55 & 97 & 176 & 356 \\
\hline AS3=R1 & 53 & 53 & 95 & 168 & 337 \\
\hline AS4=V7+V10 & 51 & 52 & 93 & 172 & 346 \\
\hline AS5=V7+R1 & 51 & 0.92 & 0.92 & 4.33 & 6.15 \\
\hline AS6=V10+R1 & 50 & 0.80 & LSD (0.05) &
\end{tabular}

All the interaction effects b/w foliar urea levels and application stages were insignificant

Grain yield and yield components

Grain yield, stover yield and yield components of maize were significantly affected by foliar urea levels and application stages. Effect of foliar urea levels and application stages was found significant on cob length (Table 2). Foliar urea spray @ $7 \%$ produced $18.6 \mathrm{~cm}$ long cobs on a par 
with foliar urea spray @ 5\% which produced $17.8 \mathrm{~cm}$ long cobs as compared to the lowest $14.7 \mathrm{~cm}$ cob length produced in control plots. Highest cob length of $17.8 \mathrm{~cm}$ was produced when foliar urea was applied at both $\mathrm{V} 7+\mathrm{V} 10$ stages respectively, followed by $17.2 \mathrm{~cm}$ cob length produced with foliar urea spray at both V10+R1 stages. Lowest cob length of $15.9 \mathrm{~cm}$ was observed when foliar urea was applied only at R1 stage. Grains $\mathrm{cob}^{-1}$ were significantly influenced with application of foliar urea levels and application stages (Table 2). Highest number of gains $\mathrm{cob}^{-1}$ (443) was produced when foliar urea was applied @ 7\% on a par with grains $\mathrm{cob}^{-1}$ (440) when sprayed @ 5\%. Lowest number of grains $\operatorname{cob}^{-1}$ (378) was produced in control plots. Number of grains $\mathrm{cob}^{-1}$ (445) were highest when foliar urea was applied at both $\mathrm{V} 7+\mathrm{V} 10$ stages respectively, followed by the number of grains $\operatorname{cob}^{-1}$ (437) with foliar urea spray at both V10+R1 stages. Lowest number of grains cob $^{-1}$ (398) was produced when foliar urea was sprayed only at R1 stage on a par with grains $\operatorname{cob}^{-1}$ (400) when applied only at V7 stage.

Foliar urea levels and application stages had significantly affected 1000 grain weight (Table 2). Highest 1000 grain weight (307 g) was recorded when foliar urea was applied @7\% on a par with 1000 grain weight (296 g) when sprayed @ 5\%. Lowest 1000 grain weight (251 g) was produced on control plots. Application of foliar urea at both V7+V10 stages produced the highest 1000 grain weight (304 g), followed by 1000 grain weight (294 g) when foliar urea was sprayed at both $\mathrm{V} 10+\mathrm{R} 1$ stages respectively. Lowest 1000 grain weight (270 g) was recorded with foliar urea spray only at R1 stage.

Significant effects of foliar urea levels and application stages were found on stover yield of maize (Table 2). Maximum stover yield $\left(11.1 \mathrm{t} \mathrm{ha}^{-1}\right)$ was produced when foliar urea was applied @7\% on a par with the stover yield $\left(10.8 \mathrm{t} \mathrm{ha}^{-1}\right)$ when foliar urea was sprayed @ 5\%. Lowest stover yield (8.8 $\mathrm{t} \mathrm{ha}^{-1}$ ) was produced in control plots. Foliar urea spray at both $\mathrm{V} 7+\mathrm{V} 10$ stages resulted in highest stover yield (11.3 $\left.\mathrm{t} \mathrm{ha}^{-1}\right)$ on a par with stover yield (10.8 $\left.\mathrm{t} \mathrm{ha}^{-1}\right)$ when foliar urea was sprayed at both V10+R1 stages. Lowest stover yield $\left(9.5 \mathrm{t} \quad \mathrm{ha}^{-1}\right)$ was produced when foliar urea was applied only at V7 stage.

Grain yield of maize was significantly affected by foliar urea levels and application stages (Table 2). Highest grain yield (4.4 t $\mathrm{ha}^{-1}$ ) was produced with the application of foliar urea@7\%, followed by grain yield (4.2 $\left.\mathrm{t} \mathrm{ha}^{-1}\right)$ when foliar urea was applied @ $5 \%$. Lowest grain yield $\left(3.3 \mathrm{t} \mathrm{ha}^{-1}\right)$ was observed in control plots. Application of foliar urea spray at both V7+V10 stages produced the highest grain yield $\left(4.7 \mathrm{t} \mathrm{ha}^{-1}\right)$, followed by grain yield $\left(4.2 \mathrm{t} \mathrm{ha}^{-1}\right)$ when foliar urea was sprayed at both $\mathrm{V} 10+\mathrm{R} 1$ stages. Lowest grain yield $\left(3.6 \mathrm{t} \mathrm{ha}^{-1}\right)$ was produced with foliar urea spray only at R1 stage. 
Table 2. Cob length (cm), grains cob ${ }^{-1}, 1000$ grain weight $(\mathrm{g})$, stover yield $\left(\mathrm{t} \mathrm{ha} \mathbf{~}^{-1}\right)$ and grain yield $\left(\mathrm{t} \mathrm{ha}^{-1}\right)$ of maize as affected by foliar urea application at different growth stages.

\begin{tabular}{|c|c|c|c|c|c|}
\hline Treatments & Cob length & Grains cob $^{-1}$ & 1000 grain weight & Stover yield & Grain yield \\
\hline \multicolumn{6}{|c|}{ Foliar Urea levels } \\
\hline N1=Control & 14.7 & 378 & 251 & 8.8 & 3.3 \\
\hline $\mathbf{N} 2=3 \%$ Urea & 16.5 & 424 & 284 & 9.9 & 4.1 \\
\hline N3=5\% Urea & 17.8 & 440 & 296 & 10.8 & 4.2 \\
\hline N4=7\% Urea & 18.6 & 443 & 307 & 11.1 & 4.4 \\
\hline $\operatorname{LSD}_{(0.05)}$ & 1.23 & 14.46 & 12.01 & 0.97 & 0.13 \\
\hline \multicolumn{6}{|c|}{ Application stages (AS) } \\
\hline AS1=V7 & 16.5 & 400 & 276 & 9.5 & 3.7 \\
\hline AS2 $=V 10$ & 17.4 & 421 & 287 & 10.1 & 4.0 \\
\hline AS3=R1 & 15.9 & 398 & 270 & 9.3 & 3.6 \\
\hline $\mathrm{AS} 4=\mathrm{V} 7+\mathrm{V} 10$ & 17.8 & 445 & 304 & 11.3 & 4.7 \\
\hline AS5 $=V 7+R 1$ & 16.8 & 425 & 277 & 9.6 & 3.8 \\
\hline AS6 $=V 10+R 1$ & 17.2 & 437 & 294 & 10.8 & 4.2 \\
\hline $\operatorname{LSD}_{(0.05)}$ & 0.79 & 6.91 & 7.21 & 0.69 & 0.24 \\
\hline
\end{tabular}

All the interaction effects $\mathrm{b} / \mathrm{w}$ foliar urea levels and application stages were insignificant

\section{Discussion}

Application of foliar urea @ 7\% when applied at both $\mathrm{V} 7+\mathrm{V} 10$ growth stages delayed days to tasseling, silking and maturity. Late season application of foliar urea had delayed days to tasseling, silking and maturity in maize $[7,9,11]$. Increased $\mathrm{N}$ application in various splits had enhanced photosynthesis [17] and delayed days to tasseling and silking in maize [14, 18]. Foliar urea sprays at both V7+V10 growth stages improved plant height and leaf area when applied @ 7\% possibly due to the increased vegetative growth of maize. Foliar urea application had increased plant height in maize when applied late during the growth period [11]. Application of foliar urea had enhanced plant height and leaf area in maize [10]. Taller plant height was observed in maize when sprayed with foliar urea at 60 DAE as compared to control (water spray) [19]. Average leaf area was improved with foliar urea spray@7\% and when applied at both V7+V10 growth stages. Delayed application of foliar urea had enhanced vegetative growth and improved leaf area in maize [11]. Foliar urea spray had resulted increase in the mean leaf area [10]. In an earlier study it had been reported that foliar $\mathrm{N}$ application time had significant effects on mean leaf area of maize [19].

Highest cob length was observed with foliar urea spray @7\% and when applied at both V7+V10 stages. The increase in cob length might be due to the delayed growth period and improved leaf area with the application of foliar urea. Highest ear length was recorded with foliar application of NPK (125\%) fertilizer [20]. Foliar urea spray @ $7 \%$ and when applied at V7+V10 growth stages improved the number of grains $\mathrm{cob}^{-1}$. Application of foliar urea enhanced vegetative growth, plant height and leaf area of maize especially when sprayed @ 7\% during the late growth stages which might have improved the number of grains $\mathrm{cob}^{-1}$. Earlier studies [21] suggested that application of foliar $\mathrm{N}$ spray increased number of grains $\mathrm{cob}^{-1}$ in maize $[5,11]$. In wheat crop, highest numbers of grains spike1 were reported [22] with the application of foliar NPK sprays. Our results are in line with the findings which found significant 
effects of $\mathrm{N}$ application on the number of grains $\mathrm{cob}^{-1}$ in maize [9]. Higher 1000 grain weight was recorded with foliar urea application @ 7\% and when applied at $\mathrm{V} 7+\mathrm{V} 10$ growth stages. The increase in grain weight might be due to the longer grain filling period resulting in more photosynthates allocation to the grains. About $90 \%$ of the required $\mathrm{N}$ for ear development is allocated from the stored $\mathrm{N}$ in stalks and leaves during anthesis and grain filling stages [23]. Foliar $\mathrm{N}$ application had increased photo-assimilates accumulation in grains resulting in improved grain weight of maize [11, 24]. Application of nitrogen at higher rates had increased photo assimilate formation and improved grain weight $[5,25,26]$. Significantly higher stover yield was obtained with foliar urea spray @ 7\% and when applied at both V7+V10 stages. The vigorous vegetative growth and improved plant height and leaf area might have resulted in increased stover yield of maize. Application of foliar $\mathrm{N}$ during the late growth stages had improved stover yield of maize [6, 11, 27]. Application of late season foliar $\mathrm{N}$ and $\mathrm{P}$ had significantly influenced straw yield in wheat [28]. Higher grain yield was produced when foliar urea was sprayed @ 7\% at V7+V10 growth stages. The improved vegetative growth period, average leaf area, grains cob${ }^{1}$ and 1000 grain weight might have resulted in higher grain yield of maize. Significantly higher grain yield had been reported in maize with foliar urea application [3, 27]. Foliar urea application had resulted in significantly higher grain yield of maize [4, 11, 29].

\section{Conclusion}

Foliar urea sprays, as a supplement to the routine soil $\mathrm{N}$ fertilization, improved vegetative growth period and grain yield when applied during periods of slow growth and flowering. Our results revealed that foliar urea sprays at the rate of $7 \%$ significantly enhanced growth, grain yield and yield components of maize when applied at both $\mathrm{V} 7+\mathrm{V} 10$ growth stages respectively.

\section{Authors' contributions}

Conceived and designed the experiment: $\mathrm{S}$ Ullah, Performed the experiment: S Ullah RM Khan \& HU Rahman, Analyzed the data: S Ullah, Contributed reagents/ materials/ analysis tools: S Ullah RM Khan \& HU Rahman, Wrote the paper: S Ullah.

\section{References}

1. Curely S, Curely RD, DeGrood D, Goff R, Hart E, Hecht R, Johnson D, Krysl E, Menghini J, Pohlman K \& Buren NV (1994). Foliar Nutrition. Midwest Laboratories, Inc., Omaha, NE.

2. Banziger M, Feil B, Schmid JE \& Stamp $P$ (1994). Utilization of late-applied fertilizer nitrogen by spring wheat genotypes. European Journal of Agronomy 3: 63-69.

3. Gooding MJ \& Davies WP (1992). Foliar urea fertilization of cereals: A review. Nutrient Cycling in Agro-ecosystems 32: 209-222.

4. Singh NT, Vig AC \& Singh R (2005). Nitrogen response of maize under temporary flooding. Nutrient Cycling in Agro-ecosystems 6: 111-120.

5. Sanjeev KA, Bangarwa S \& Kumar S (1997). Yield and yield components of winter maize as influenced by plant density and N levels. Agriculture Science 17: 181-184.

6. Woolfolk CW, Rawn WR, Johanson GV, Thomson WF, Mulan RW, Wynn KJ \& Freeman KW (2002). Influence of late season foliar application of $\mathrm{N}$ in maize. American Society of Agronomy Production Paper 94: 429-434.

7. Karim M, Baksh A \& Shah P (1983). Effect of plant population, $\mathrm{N}$ application and irrigation on yield of synthetic maize. Journal of Agriculture Research 21: 5769. 
8. Below FE, Crafts-Brabender SJ, Harper JE \& Hageman RH (1985). Uptake, distribution, and remobilization of $15 \mathrm{~N}$ labelled urea applied to maize canopies. Agronomy Journal 77: 412-415.

9. Douby KA, Ali EA, Toaima SEA \& Aziz AMA (2000). The effect of $\mathrm{N}$ levels and defoliation on maize yield. Crop Research 24: 96-101.

10. Shimshi D (1967). Leaf chlorosis and stomatal aperture. New Phytologist 66: 455-461.

11. Amanullah, Yasir M, Khalil SK, Jan MT \& Khan AZ (2010a). Phenology, growth and grain yield of maize as influenced by foliar applied urea at different growth stages. Journal of Plant Nutrition 33: 71-79.

12. Balman P \& Smith DL (1991). Grain protein response of spring barley to high rates and post-anthesis application of fertilizer nitrogen. Agronomy Journal 85: 1109-1113.

13. Amanullah, Rahman H, Shah Z \& Shah $P$ (2008). Effects of plant density and N on growth dynamics, light interception and yield of maize. Archives of Agronomy and Soil Science 54: 401-411.

14. Amanullah, Shah P \& Marwat KB (2009). Nitrogen levels and its time of application influence leaf area, height and biomass of maize planted at low and high density. Pakistan Journal of Botany 41: 761-768.

15. Carangal VR, Ai SM, Koble AF, Rinke BH \& Senpz JC (1971). Comparison of S1 with test cross evaluation for recurring selection in maize. Crop $S c i$ 11: 658-661.

16. Steel RGD \& Torrie JH (1980). Analysis of Variance, In: Principles and Procedures of Statistics: A Biometrical Approach, pp. 401-437. McGraw-Hill, New York.

17. Oikeh SO, Kling JK, Horst W \& Chude VO (1997). Yield and N-Use efficiency of five tropical maize genotypes under different $\mathrm{N}$ levels in the moist savanna of Nigeria. p. 163-167. In: Proceedings of the Fifth Eastern and Southern Africa Regional Maize Conference. J.K. Ransom (ed.). Addis Ababa: CIMMYT. June 3-7, 1996, Arusha, Tanzania.

18. Gungula DT, Kling JG \& Togun AO (2003). CERES Maize predictions of maize phenology under nitrogen stressed conditions in Nigeria. Agronomy Journal 95: 892-899.

19. Amanullah, Khan AZ \& Khan F (2013). Foliar application of nitrogen at different growth stages influences the phenology, growth and yield of maize (Zea mays L.). Soil and Environment 32: 135-140.

20. Fattah AA, Selim EM \& Awad EM (2012). Response of corn plants (Zea mays L.) to soil and foliar applications of mineral fertilizers under clay soil conditions. Journal of Applied Sciences and Research 8(8): 4711-4719.

21. Sarandon SJ \& Gianibelli MC (1990). Effect of foliar urea spraying and nitrogen application at sowing upon dry matter and nitrogen distribution in wheat (Triticum aestivum L). Agronomie 10: 183-189.

22. Arif, M, Chohan MA, Ali S, Gul R \& Khan S (2006). Response of wheat to foliar application of nutrients. Journal of Agriculture \& Biological Science 1: 3034.

23. Ta CT \& Weiland RT (1992). Nitrogen partitioning in maize during ear development. Crop Science 32: 443451.

24. Harder HJ, Carlson RE \& Shaw RH (1982). Leaf photosynthetic response to foliar fertilizer applied to corn plants during grain fill. Agronomy Journal 74: 759-761.

25. Strong WM (1982). Effect of late application of nitrogen on the yield and protein content of wheat. Australian 
Journal of Experimental Agriculture and Animal Husbandry 22: 54-61.

26. Lawlor DW, Milford GFJ, Mitchell VJ \& Mitchell RAC (1989). Effects of foliar-applied urea on leaf composition, photosynthesis and grain quality and yield. Abstract 58. In: Plant and Soil Nitrogen Metabolism. Proceedings of AFRC meeting, Sept. 1989. Lancaster University.

27. Amanullah, Zakirullah M \& Khalil SK (2010b). Timing and rate of $P$ application influence maize phenology, yield and profitability in Northwest Pakistan. International Journal of Plant Production 4: 281-292.
28. Alston AM (1979). Effects of soil water content and foliar fertilization with nitrogen and phosphorus in late season on the yield and composition of wheat. Australian Journal of Experimental Agriculture and Animal Husbandry 30: 577-585.

29. Dampney PMR \& Salmon SE (1990). The effect of rate and timing of late nitrogen applications to bread-making wheat as ammonium nitrate or foliar urea-N, and the effect of foliar sulphur application I. Effect on yield, grain quality and recovery of nitrogen in grain. Aspects of Applied Biology 25: 229-242. 